\title{
Cord haemoglobin in low birthweight infants
}

\author{
DAVID BURMAN and AUDREY F. MORRIS \\ From the Departments of Child Health and Public Health, University of Bristol
}

Burman, D., and Morris, A. F. (1974). Archives of Disease in Childhood, 49, 382. Cord haemoglobin in low birthweight infants. Cord haemoglobin was measured in 349 low birthweight infants born after a pregnancy lasting 28 to 41 weeks inclusive. 82 babies were small-for-dates and were born after 36 weeks' gestation; their $\mathrm{Hb}$ was not related to sex or duration of pregnancy, but there was a negative correlation with placental weight and placental weight/birthweight ratios. The mean $\mathrm{Hb}$ of small-fordates babies $(17 \cdot 09 \pm 2 \cdot 11 \mathrm{~g} / 100 \mathrm{ml})$ was higher than for comparable normal babies $(16 \cdot 24 \pm 2 \cdot 26 \mathrm{~g} / 100 \mathrm{ml})$.

In normal-for-dates females there was a linear relation between $\mathrm{Hb}$ and duration of pregnancy approximately expressed by: $\operatorname{cord~} \mathrm{Hb}(\mathrm{g} / 100 \mathrm{ml})=7+$ gestational age in lunar months. In males a plateau $\mathrm{Hb}$ of $16 \cdot 22 \mathrm{~g} / 100 \mathrm{ml}$ was reached at 32 weeks.

Surprisingly, there are very few studies on cord $\mathrm{Hb}$ levels in low birthweight infants. Schulman (1959) reviewed the series published until 1957 and pointed out the paucity of information between 24 and 36 weeks' gestation. Corner (1960) showed a rising $\mathrm{Hb}$ with duration of pregnancy in 83 cases, but we know of no other large scale study of infants born after 28 weeks' pregnancy. To remedy this situation, this retrospective investigation was undertaken.

\section{Methods}

The records of 765 singletons weighing $2.5 \mathrm{~kg}$ or less, born alive in Bristol Maternity Hospital during 1965-71 were studied. One record could not be found but, of the remainder, 360 had cord $\mathrm{Hb}$ estimated by the standard cyanmethaemoglobin method using an EEL colorimeter and Acuglobin standards (Ortho Pharmaceuticals Ltd.). The blood was collected from the umbilical vein by a syringe and needle. The 360 with $\mathrm{Hb}$ measurements did not differ significantly from the remaining 404 in respect of maternal age, social class, legitimacy, number of previous pregnancies, sex, mode of delivery, placental weight/birthweight ratio, and mother's mean $\mathrm{Hb}$ taken within 28 days of delivery by the $\chi^{2}$ test. There was, however, a significant excess of emergency admissions and mothers whose $\mathrm{Hb}$ was not known in the infants where the cord blood was not taken (Table I).

The period of gestation used was that assessed by the obstetrician and recorded at the time of delivery. It is expressed in completed weeks and was known for 758 of all the infants. If the distribution of gestational ages of these low birthweight infants are compared in 2-week groups with the national sample of Butler and Bonham

Received 5 October 1973.
TABLE I

Significant differences between babies with a known cord $\mathrm{Hb}$ and those where it was not recorded

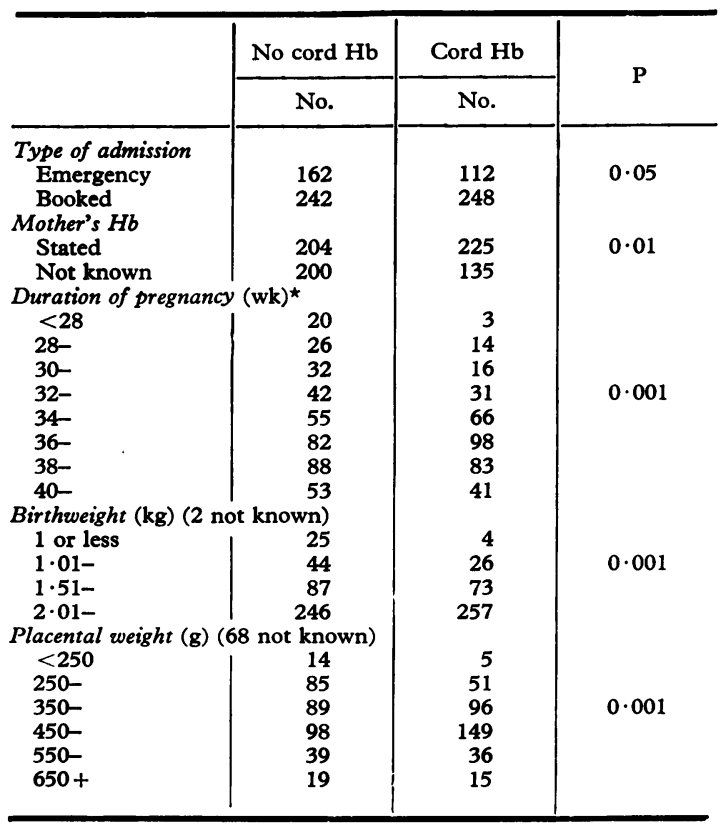

${ }^{\star}$ Excluding 8 born after 42 weeks and 6 not known.

(1963), there is a significant difference $(P<0.01)$. Virtually one-half of the contributions to the $\chi^{2}$ test was in infants over 42 weeks who were deficient in the Bristol series. If these are eliminated, the Bristol and national 
TABLE II

Mean cord $\mathrm{Hb}$ in 349 low birthweight infants

\begin{tabular}{|c|c|c|c|c|c|c|c|c|c|}
\hline \multirow{4}{*}{$\begin{array}{l}\text { Completed weeks } \\
\text { of gestation }\end{array}$} & \multicolumn{6}{|c|}{ Appropriate weight for dates } & \multirow{2}{*}{\multicolumn{3}{|c|}{$\begin{array}{l}\text { Small-for-dates } \\
\text { males and females }\end{array}$}} \\
\hline & \multicolumn{3}{|c|}{ Males } & \multicolumn{3}{|c|}{ Females } & & & \\
\hline & \multirow{2}{*}{ No. } & \multicolumn{2}{|c|}{$\mathrm{Hb}(\mathrm{g} / 100 \mathrm{ml})$} & \multirow{2}{*}{ No. } & \multicolumn{2}{|c|}{$\mathrm{Hb} / \mathrm{g} / 100 \mathrm{ml}$} & \multirow{2}{*}{ No. } & \multicolumn{2}{|c|}{$\mathrm{Hb}(\mathrm{g} / 100 \mathrm{ml})$} \\
\hline & & Mean & SD & & Mean & SD & & Mean & SD \\
\hline $\begin{array}{l}28,29 \\
30,31 \\
32,33 \\
34,35 \\
36,37 \\
38,39 \\
40,41\end{array}$ & $\begin{array}{r}7 \\
9 \\
16 \\
32 \\
46 \\
17 \\
\text { Nil }\end{array}$ & $\begin{array}{c}15 \cdot 00 \\
15 \cdot 91 \\
16 \cdot 29 \\
16 \cdot 29 \\
16 \cdot 20 \\
16 \cdot 22 \\
-\end{array}$ & $\begin{array}{c}2 \cdot 45 \\
1 \cdot 34 \\
1 \cdot 86 \\
2 \cdot 05 \\
2 \cdot 20 \\
2 \cdot 24 \\
-\end{array}$ & $\begin{array}{r}7 \\
7 \\
15 \\
32 \\
39 \\
33 \\
5\end{array}$ & $\begin{array}{l}13 \cdot 60 \\
14 \cdot 73 \\
15 \cdot 21 \\
15 \cdot 82 \\
15 \cdot 88 \\
16 \cdot 68 \\
16 \cdot 56\end{array}$ & $\begin{array}{l}2 \cdot 16 \\
1 \cdot 07 \\
2 \cdot 64 \\
2 \cdot 43 \\
2 \cdot 45 \\
2 \cdot 23 \\
1 \cdot 65\end{array}$ & $\begin{array}{c}\text { Nil } \\
\text { Nil } \\
\text { Nil } \\
2 \\
13 \\
33 \\
36\end{array}$ & $\begin{array}{c}- \\
- \\
15 \cdot 25 \\
17 \cdot 44 \\
17 \cdot 02 \\
17 \cdot 03\end{array}$ & $\begin{array}{l}- \\
- \\
\bar{Z} \\
2 \cdot 27 \\
2 \cdot 09 \\
2 \cdot 12\end{array}$ \\
\hline
\end{tabular}

samples did not differ significantly. It was therefore decided that infants over 42 weeks should be excluded from the analysis.

The babies with cord $\mathrm{Hb}$ measurements were compared with the rest of the Bristol sample and their distribution by gestational age was significantly different (Table I). The major contribution to the $\chi^{2}$ test was infants born before 28 weeks, and if these were omitted then the difference between the two groups is only just significant $(P<0.05)$. If the remaining 349 infants with known cord $\mathrm{Hb}$, born between 28 and 41 weeks inclusive, are compared with Butler and Bonham (1963) then the difference is just significant $(P<0.05)$ but the national sample contained $11 \cdot 3 \%$ where the period of gestation was unknown compared with $1 \%$ in the present series.

By similar comparisons it was found that there was a conspicuous shortage of infants with a weight less than $1 \mathrm{~kg}$ and with a placental weight of less than $350 \mathrm{~g}$ in the cord $\mathrm{Hb}$ infants compared with those whose $\mathrm{Hb}$ was not measured (Table I). Omission of these low birthweight infants with a small placenta eliminates the statistical differences between the two groups.

From these data it is clear that there is a group of babies born to mothers, admitted to Bristol Maternity Hospital as emergencies with no maternal $\mathrm{Hb}$ measurement, who do not have their cord $\mathrm{Hb}$ taken. They are the very premature infants of low birthweight with a very low placental weight. If babies born between 28 and 41 weeks inclusive are considered, then the present sample is reasonably representative of low birthweight babies and it is these 349 infants whose results are recorded here.

Infants are considered small-for-dates if their birthweight for gestation was $2 \mathrm{SD}$ below the mean using Gruenwald's (1969) data.

\section{Results}

Of the 349 infants discussed here, 84 were smallfor-dates (Table II). All except 2 of these were born after 36 weeks' gestation and if the 82 remaining cases are analysed by the two-factor analysis of variance with proportional subclass numbers previously described (Burman, 1972), there is no relation of $\mathrm{Hb}$ to sex or period of gestation. From 34 to 38 weeks, there was no relation between cord $\mathrm{Hb}$ and sex or period of gestation in babies whose weight was appropriate for dates. It is therefore possible to compare the small-for-dates and normal-for-dates babies in later pregnancy ignoring sex and period of gestation. The significant difference between the $\mathrm{Hb}$ in these two groups is shown in Table III. Correlations

\section{TABLE III}

Cord $\mathrm{Hb}$ in low birthweight infants of both sexes born between 36 and 42 weeks' gestation

\begin{tabular}{l|c|c|c}
\hline & & \multicolumn{2}{|c}{$\mathrm{Hb}(\mathrm{g} / 100 \mathrm{ml})$} \\
\cline { 2 - 3 } & No. & Mean & SD \\
\hline Normal-for-dates & 140 & $16 \cdot 24$ & $2 \cdot 26$ \\
Small-for-dates & 82 & $17 \cdot 09$ & $2 \cdot 11$ \\
\hline
\end{tabular}

$t=2 \cdot 783 ; P<0 \cdot 01$.

between cord $\mathrm{Hb}$ and other parameters were sought in these two groups and the results are shown in Table IV.

In the normal-for-dates infants the difference between the cord $\mathrm{Hb}$ of the two sexes is shown in Table II. At any single gestational age the difference between the sexes is not significant at the $5 \%$ level. Before 34 weeks, however, two-factor analysis of variance showed a significant difference between the sexes (Table V). This difference is not due to difference in birthweight, placental weight, or placental weight/birthweight ratios, for at each 2-week gestation period there is no significant difference between the sexes as far as these parameters are concerned, and there is no consistent 
TABLE IV

Correlation coefficients $(r)$ between cord $\mathrm{Hb}$ and other parameters in low birthweight infants born between 36 and 42 weeks' gestation

\begin{tabular}{|c|c|c|c|c|c|c|}
\hline \multirow{2}{*}{$\begin{array}{l}\text { Correlation coefficients }(r) \\
\text { between cord } \mathrm{Hb} \text { and }\end{array}$} & \multicolumn{3}{|c|}{ Normal-for-dates } & \multicolumn{3}{|c|}{ Small-for-dates } \\
\hline & No. & $\mathbf{r}$ & $\mathbf{P}$ & No. & $\mathbf{r}$ & $\mathbf{P}$ \\
\hline
\end{tabular}

TABLE V

Two-factor analysis of variance to show effect of sex upon cord $\mathrm{Hb}$ in infants born from 28 to 33 weeks' gestation inclusive

\begin{tabular}{|c|c|c|c|c|c|}
\hline Variation & df & $\begin{array}{l}\text { Sum of } \\
\text { squares }\end{array}$ & $\begin{array}{c}\text { Mean } \\
\text { square }\end{array}$ & $\begin{array}{l}\text { Variance } \\
\text { ratio }\end{array}$ & $\mathbf{P}$ \\
\hline $\begin{array}{l}\text { Sex } \\
\text { Gestation } \\
\text { Sex and } \\
\quad \text { gestation }\end{array}$ & $\begin{array}{l}1 \\
2 \\
2\end{array}$ & $\begin{array}{r}2120 \\
2016 \\
25\end{array}$ & $\begin{array}{r}2120 \cdot 000 \\
1008 \cdot 000 \\
12 \cdot 500\end{array}$ & $\begin{array}{l}4 \cdot 949 \\
2 \cdot 353 \\
0 \cdot 029\end{array}$ & $\begin{array}{c}<0.05 \\
\text { NS } \\
\text { NS }\end{array}$ \\
\hline $\begin{array}{l}\text { Total between } \\
\text { cells } \\
\text { Subjects within } \\
\text { cells }\end{array}$ & $\begin{array}{r}5 \\
55\end{array}$ & $\begin{array}{r}4161 \\
23,561\end{array}$ & $\begin{array}{l}832 \cdot 200 \\
428 \cdot 382\end{array}$ & & \\
\hline
\end{tabular}

NS, not significant.

trend. The Fig. shows that the shape of the curve differs in the two sexes. Males whose weights are normal-for-dates reach a maximum cord $\mathrm{Hb}$ at 32 weeks, remaining constant with a mean of $16 \cdot 22$ $\mathrm{g} / 100 \mathrm{ml}$ until 38 weeks when the present data stop. Females, however, show a steady increase in $\mathrm{Hb}$ from 28 to 41 weeks and the regression line is expressed by the formula

$\mathrm{Hb}(\mathrm{g} / 100 \mathrm{ml})=7 \cdot 016+0 \cdot 245$ (gestational age in completed weeks).

There was a strong correlation between gestation and birthweight in both the small-for-dates and normal-for-dates babies. The $\mathrm{Hb}$ levels related to birthweight followed the same trend as $\mathrm{Hb}$ to gestation, but the relation was less clear cut. As the criterion for admission to the survey was based on birthweight, it was considered that gestation was the better parameter for these data as the primary measure of maturity.

\section{Discussion}

This series of low birthweight infants emphasizes the importance of separating those who are smallfor-dates from those whose weight is appropriate for dates. The criterion used here ( 2 SD below the mean using the data of Gruenwald, 1969) is very stringent. The high $\mathrm{Hb}$ level in these infants confirms earlier observations of Walker and Turnbull (1953) and MacKay (1957) who produced evidence suggesting a relation between $\mathrm{Hb}$ and the degree of neonatal anoxia. This could not be

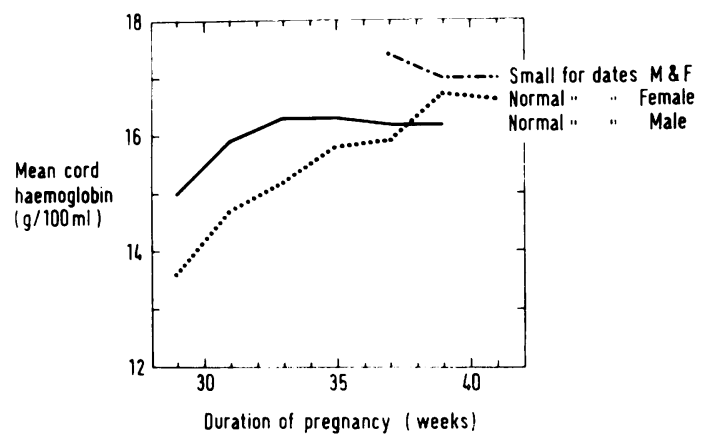

FIG.-The mean cord $\mathrm{Hb}$ of low birthweight babies born between 28 and 42 weeks of pregnancy.

confirmed by Rooth and Sjöstedt (1957), but ZachauChristiansen, Hoff-Jørgensen, and Østergäard Kristensen (1962) and Haworth, Dilling, and Younoszai (1967) confirmed higher $\mathrm{Hb}$ levels in severely growth-retarded infants. Humbert et al. (1969) also confirmed Walker and Turnbull's work and described symptoms produced by neonatal polycythaemia in a few of these infants. Lugo and Cassady (1971) showed that polycythaemia was twice as common in the growth-retarded infants as in the mature normal birthweight or immature low birthweight infants.

The mechanism by which this high $\mathrm{Hb}$ is produced seems to be due to an increased production of red cells by the bone marrow, for Finne (1966) found higher erythropoietin levels in cord blood in the postmature and in infants born to mothers suffering from toxaemia of pregnancy. Seip (1955) found higher reticulocyte levels in asphyxiated babies, but Cook, Brodie, and Allen (1957) and Lochridge, Pass, and Cassady (1971) thought that 
reticulocytes in growth-retarded infants were commensurate with their gestational peers rather than their weight peers. The high $\mathrm{Hb}$ can also be explained if the suggestion of Cook et al. (1957), that it is due to haemoconcentration, is true, and Flod and Ackerman (1971) found that perinatal asphyxia results in the transfer of blood in utero from placenta to fetus.

In the small-for-dates infants there was no correlation between the cord $\mathrm{Hb}$ and birthweight, but there was a negative correlation with placental weight and placental weight/birthweight ratios, correlations which were absent in the normal for dates (Table IV). The functional significance of placental weight and its relation to fetal weight has been considered to be very limited by Thomson, Billewicz, and Hytten (1969), but they also point out that it depends upon the margin of placental reserve which for oxygen is low. Factors related to oxygen tension, such as $\mathrm{Hb}$, would be a sensitive indication of placental function and this would account for the relations between cord $\mathrm{Hb}$ and placental weight and placental weight/birthweight ratio shown here. Aherne (1966) thought that placental weight was related to chorionic villous surface area and fetal oxygen uptake and thus was of functional significance, but one must agree with Little (1960) that only marked deviations are of clinical importance. Gruenwald (1963) stated that the 'weight of the placenta is by no means a good measure of size in the functional sense, but no better parameter is available for routine determinations'. He found that if the placental weight for gestation or for birthweight was $2 \mathrm{SD}$ below the mean, the perinatal mortality was increased sixfold.

Aherne (1966) suggested that total fetal metabolism varies as the $2 / 3$ power of fetal weight and that this was directly related to placental weight. We therefore recalculated the correlation coefficients between cord $\mathrm{Hb}$ and placental weight/birthweight ratios using placental weight/birthweight ${ }^{\frac{2}{3}}$ instead. This increased the correlation coefficient in the small-for-dates from 36 to 41 weeks insignificantly from $-0 \cdot 227$ to $-0 \cdot 243$.

The lower $\mathrm{Hb}$ in the low birthweight babies whose weight is appropriate for duration of pregnancy has been suggested before by Schulman (1959), but he admitted that the data were incomplete. The difference between the two sexes reported here has not been found before and certainly needs confirming. We have no explanation for this difference, but attempts to explain it in terms of birthweight, placental weight, and placental weight/birthweight ratio were unsuccessful in the present series.
The linear relation between $\mathrm{Hb}$ and duration of pregnancy in the female fetus can be approximately expressed by the formula

cord $\mathrm{Hb}(\mathrm{g} / 100 \mathrm{ml})=7+$ gestational age in lunar months.

This gives a term $\mathrm{Hb}$ of $17 \cdot 0 \mathrm{~g} / 100 \mathrm{ml}$, which is the figure observed in many series (Burman, 1959).

\section{REFERENCES}

Aherne, W. (1966). A weight relationship between the human foetus and placenta. Biologia Neonatorum, 10, 113.

Burman, D. (1959). The normal cord haemoglobin level. Fournal of Obstetrics and Gynaecology of the British Empire, 66, 147.

Burman, D. (1972). Haemoglobin levels in normal infants aged 3 to 24 months, and the effect of iron. Archives of Disease in Childhood, 47, 261.

Butler, N. R., and Bonham, D. G. (1963). Perinatal Mortality. First Report of the 1958 British Perinatal Mortality Survey, p. 143. Livingstone, Edinburgh.

Cook, C. D., Brodie, H. R., and Allen, D. W. (1957). Measurement of fetal hemoglobin in newborn infants. Correlation with gestational age and intrauterine hypoxia. Pediatrics, 20, 272.

Corner, B. (1960). Prematurity, p. 75. Cassell, London.

Finne, P. H. (1966). Erythropoietin levels in cord blood as an indicator of intrauterine hypoxia. Acta Paediatrica Scandinavica, 55, 478.

Flod, N. E., and Ackerman, B. D. (1971). Perinatal asphyxia and residual placental blood volume. Acta Paediatrica Scandinavica, 60, 433.

Gruenwald, P. (1963). Chronic fetal distress and placental insufficiency. Biologia Neonatorum, 5, 215.

Gruenwald, P. (1969). The Second Report of the 1958 British Perinatal Mortality Survey, p. 142 . Ed. by N. R. Butler and E. D. Alberman. Livingstone, Edinburgh.

Haworth, J. C., Dilling, L., and Younoszai, M. K. (1967). Relation of blood-glucose to haematocrit, birthweight, and other body measurements in normal and growth-retarded newborn infants. Lancet, 2, 901.

Humbert, J. R., Abelson, H., Hathaway, W. E., and Battaglia, F. C. (1969). Polycythemia in small for gestational age infants. Fournal of Pediatrics, 75, 812.

Little, W. A. (1960). The significance of placental/fetal weight ratios. American fournal of Obstetrics and Gynecology, 79, 134.

Lochridge, S., Pass, R., and Cassady, G. (1971). Reticulocyte counts in intrauterine growth retardation. Pediatrics, 47, 919.

Lugo, G., and Cassady, G. (1971). Intrauterine growth retardation. Clinico-pathologic findings in 233 consecutive infants. American fournal of Obstetrics and Gynecology, 109, 615.

MacKay, R. B. (1957). Observations on the oxygenation of the foetus in normal and abnormal pregnancy. Fournal of Obstetrics and Gynaecology of the British Empire, 64, 185.

Rooth, G., and Sjöstedt, S. (1957). Haemoglobin in cord blood in normal and prolonged pregnancy. Archives of Disease in Childhood, 32, 91.

Schulman, I. (1959). Characteristics of the blood in foetal life. In Oxygen Supply to the Human Foetus, p. 43. Ed. by J. Walker and A. C. Turnbull. Blackwell, Oxford.

Seip, M. (1955). The reticulocyte level, and the erythrocyte production judged from reticulocyte studies, in newborn infants during the first week of life. Acta Paediatrica, 44, 355.

Thomson, A. M., Billewicz, W. Z., and Hytten, F. E. (1969). The weight of the placenta in relation to birth weight. Fournal of Obstetrics and Gynaecology of the British Commonwealth, 76, 865.

Walker, J., and Turnbull, E. P. N. (1953). Haemoglobin and red cells in the human foetus and their relation to the oxygen content

of the blood in the vessels of the umbilical cord. Lancet, 2, 312.
Zachau-Christiansen, B., Hoff-Jørgensen, E., and Ostergäard Kristensen, H. P. (1962). The relative haemoglobin; iron, Vit $\mathrm{B}_{12}$ and folic acid values in the blood of mothers and their newborn infants. Danish Medical Bulletin, 9, 157.

Correspondence to Dr. D. Burman, Bristol Royal Hospital for Sick Children, Bristol BS2 8BJ. 